\title{
海面埋立水底土砂処分場における 植物プランクトンの増殖と水質の変動
}

\author{
Growth of Phytoplankton and Changes in Water Quality \\ in a Sea-based Dredged Soil Disposal Site
}

西尾孝之、藤原康博、芳倉太郎、福永 勲

\author{
大阪市立環境科学研究所／テ543-0026 大阪市天王寺区東上町8-34
}

\author{
TAKAYUKI NISHIO, YASUHIRO FUJIWARA, TARO YOSHIKURA, and ISAO FUKUNAGA \\ Osaka City Institute of Public Health and Environmental Sciences \\ 18-34 Tojo, Tennoji, Osaka 543-0026
}

\begin{abstract}
The relations between proliferation of phytoplankton and changes in water quality were examined to control the water quality in the lagoon of a sea-based dredged soil disposal site.

Correlation of Chl. $a$ with BOD and COD was high, and it was implied that organic pollution was mainly caused by the primary production in the lagoon when hydraulic retention time become long. Because high $\mathrm{pH}$ of the wastewater was a problem, factors that influence $\mathrm{pH}$ were analyzed. The results of the simulation of $\mathrm{pH}$ changes in the lagoon from IC concentration was fairly reasonable; however, changes in the IC concentration was only partly explained by the proliferation of phytoplankton. Factors that influence IC concentration other than proliferation of phytoplankton remained unresolved.
\end{abstract}

Key words : primary production, $\mathrm{CO}_{2}, \mathrm{BOD}, \mathrm{COD}$, solid waste disposal site

\section{1.はじめに}

植物プランクトンの増殖に伴い水質が悪化する例は, 瀬戸内海や大阪湾等の閉鎖水域において報告されており， 特にCODやBODの内部生産や $\mathrm{pH}$ の上昇が問題となって いる ${ }^{1-4)}$ 。

污染のない海域の海水は弱塩基性で, $\mathrm{pH}$ は8.0〜8.3程 度である ${ }^{5 !}$ 。海水の $\mathrm{pH}$ を支配するのは海水中の弱酸であ りその大部分を炭酸が占めるが, 植物プランクトンの増 殖に伴う炭酸の消費が起こると $\mathrm{pH}$ は上昇する。閉鎖海域 の瀬戸内海や大阪湾においても，植物プランクトンの増 殖に伴う $\mathrm{pH}$ の上昇が報告されている ${ }^{6}$ 。

大阪市では, 大阪港湾域の水底土砂を大阪湾奥部に位
置する海面埋立水底土砂処分場に処分している。この水 底土砂処分場では, 内水の滞留時間が長い時期に植物プ ランクトンの大増殖が起こり内水の $\mathrm{pH}$ が排水基準の 9.0 を超えることがあるので，土砂投入に伴う余水は余水吐 きにおいて懸濁物質や $\mathrm{pH}$ 等を適正に処理した後, 排水し ている。

我々は, 植物プランクトン増殖と $\mathrm{pH}$ の関係を理解して 海面埋立水底土砂処分場内水の水質管理を適正に行うた め, 水質污濁項目とクロロフィルの調査を行い, 植物プ ランクトンの増殖と水質污濁との関係, 特にIC と $\mathrm{pH}$ 変 動について考察した。 


\section{2. 実釦材料および方法}

北港処分地南地区内水における採水地点をFig. 1に示 す。1区は一般廃棄物焼却残滓や不燃性固形廃棄物,

$2 \cdot 3$ 区には港湾域の浚渫水底土砂や陸上建設残土が投 入されている。1区余水はポンプにより $2 \cdot 3$ 区へ日量 約 $3,000 \mathrm{~m}^{3}$ 排水されている。1999年 4 月から 2000 年 3 月 までの調査期間中, $2 \cdot 3$ 区への水底土砂の投入量は例 年の半分以下で，年間約 $920,000 \mathrm{~m}^{3}$ であった。

北港処分地南地区内水を毎週 1 回採取し, 工場排水試 験方法 (JIS K0102 $)^{7}$ に準拠して化学的酸素要求量 (COD), 生物化学的酸素要求量 (BOD), 無機炭素 (IC), 全有機炭素 (TOC), 眯濁態有機炭素濃度 (POC), 懸濁 物質 $(\mathrm{SS})$, 塩素イオン $\left(\mathrm{Cl}^{-}\right)$, 水素イオン濃度 $(\mathrm{pH})$ を測定した。POCは,ガラス繊維ろ紙（GS25, Advantech TOYO）を用いてろ過した試料のDOC（溶解性全有機炭 素）を測定し，TOCから差し引いて求めた。 $\mathrm{pH} 4.8$ アル カリ度は「水の分析」 に従い測定した。クロロフィル $a$ (Chl. $a)$ とフェオフィチン $a$ (Pheo. $a$ ) は海洋観測指針 ${ }^{9}$ に従い蛍光光度法により測定した。

\section{3. 結果および考察}

\section{1 クロロフィルaと水質の季節変化}

内水における Chl. $a, \mathrm{BOD}, \mathrm{COD}$ の経月変化を Fig. 2-left に示す。1区（P4）においてはCODはBODに比べて高 いことから難分解性 CODの存在比率が高いことや, BOD が植物プランクトン量を示すクロロフィル $\mathrm{a}$ と相関が低 い $(\mathrm{r}=0.119)$ ことから埋め立てた廃棄物浸出余水中の 有機物の影響が大きいことが判った。一方，2·3区では $\mathrm{S} 5$ のCODを除いて Chl. $a$ と BOD, CODの相関が高く（P $<0.05 ; \mathrm{r}=0.37 \sim 0.89, \mathrm{n}=49), 2 \cdot 3$ 区における有機 物量の変動は内部生産によるものであることが強く示唆 された（Fig.2-right）。森ら ${ }^{3.4}$ も当処分場内水における Chl. $a$ と CODの関係について同様のことを指摘している。 水底土砂を投入していない時期は滞留時間が長くなるこ とに加え, 底泥からの栄養塩類の溶出が植物プランクト ンの増殖を招くものと考えられ，植物プランクトン対策 が内水のCOD対策につながるものと考えられる。

北港処分地南地区内各地点の Chl. $a$ と IC 濃度および $\mathrm{pH}$ の経時変化をFig.3に示す。1区（P 4) では春期に珪 藻類のChaetoceros spp. が優占し, Chl. $a$ が比較的高濃 度になったが，2·3区に比べると非常に低かった。2・ 3 区は周期的に高密度に植物プランクトンが増殖し, 2

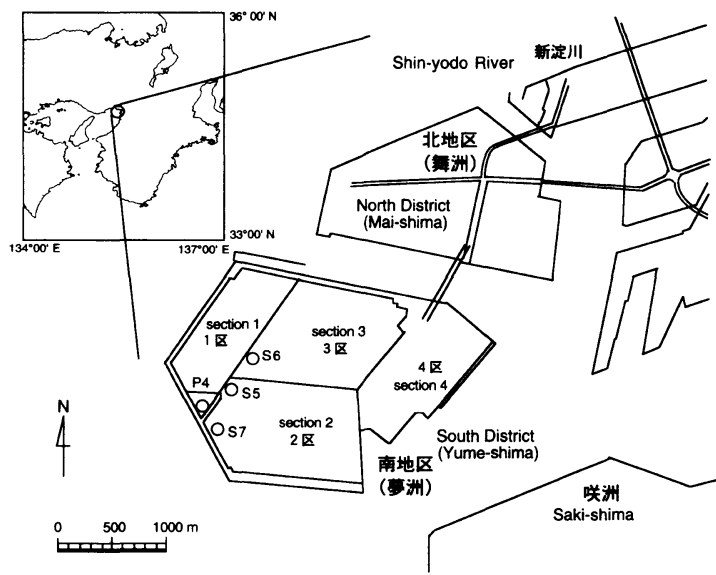

Fig. 1 Sampling sites in the North Port sea-based dredged soil disposal site south station.

区（S5·S7）では 3〜4，6，8，10，1月に，3区（S 6）では10，11月に多かった。特にS7では10月に1300mg $\mathrm{m}^{-3}$ に達し，2 区では緑藻類のOocystis submarina，3 区では渦鞭毛藻類のProrocentrum minimumが優占種で あった。

Chl. $a$ と $\mathrm{pH}$ ではピークの時期がずれたり, $\mathrm{pH}$ 変化量 がChl. $a$ 濃度に必ずしも正比例するわけではないが， 1 区を除いてChl. $a$ と $\mathrm{pH}$ の間には有為の正の相関 $(\mathrm{P}<$ $0.05 ; \mathrm{r}=0.35 \sim 0.62 ; \mathrm{n}=49)$ が認められた（Table 1)。1 区はICの值が他の地点よりも高く，植物プラン クトンによる $\mathrm{pH}$ や ICの変動割合は低かった。一方, $\mathrm{pH}$ と ICは，1区のP4 $(\mathrm{r}=0.164 ; \mathrm{P}>0.1)$ を除くと逆の相 関が比較的高く，相関係数はS5, S6, S7でそれぞれ $0.249(\mathrm{P}<0.1), 0.366(\mathrm{P}<0.05), 0.422(\mathrm{P}<0.01)$ で あった（Table 1)。Chl. $a$ と pH, ICと pHの間にそれぞ れ関係があることから，植物プランクトンの増殖に伴う 炭酸同化作用による海水中炭酸塩濃度の減少が海水の $\mathrm{pH}$ の上昇に影響を及ほすことを示唆していた。そこで， 植物プランクトンと $\mathrm{pH}$ の関係を詳細に検討した。

Table 1 Correlation coefficients between $\mathrm{pH}, \mathrm{IC}$, and Chl.a.

\begin{tabular}{cccc}
\hline & pH vs IC & pH vs Chl. a & IC vs Chl. a \\
\hline P4 & 0.164 & 0.040 & 0.459 \\
S5 & 0.249 & 0.618 & 0.166 \\
S6 & 0.366 & 0.397 & 0.019 \\
S7 & 0.422 & 0.346 & 0.156 \\
\hline
\end{tabular}



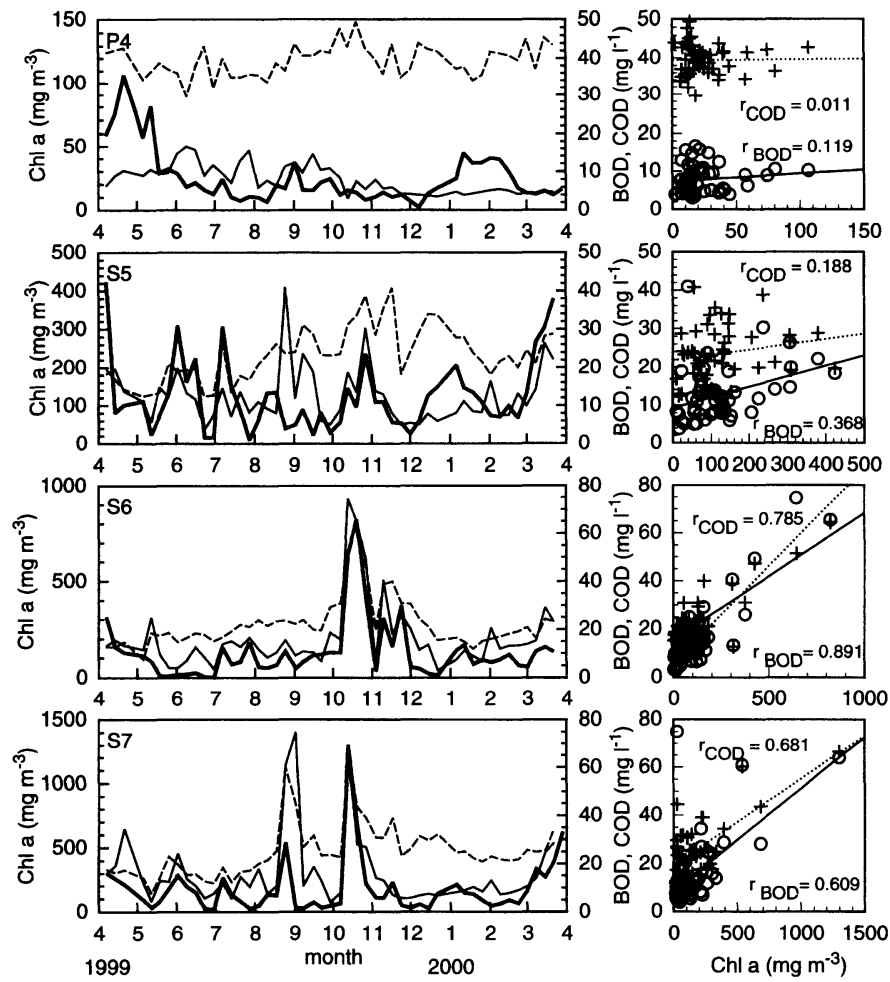

(A)
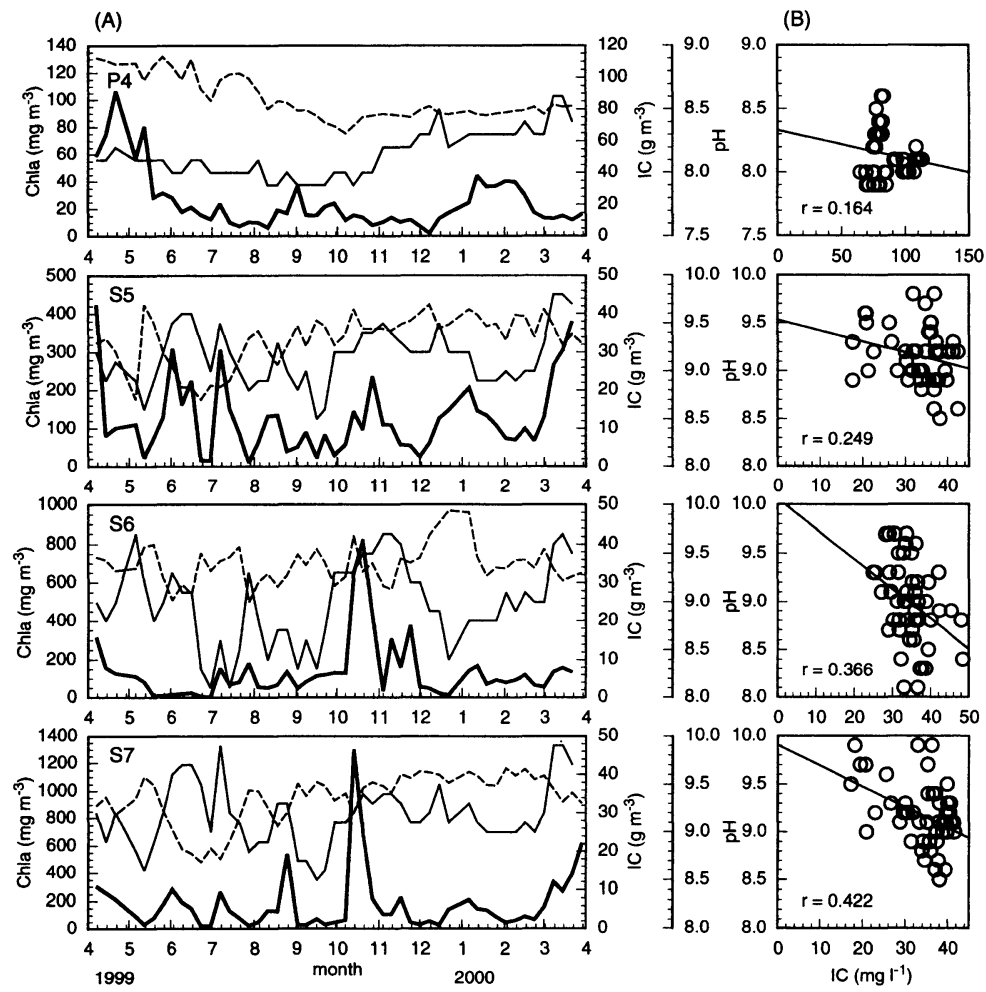

Fig. 2 Seasonal changes and correlation between Chl.a with BOD and COD in the North Port sea-based dredged soil disposal site south station.

Heavy (-), light (-), and broken $(---)$ lines in the left panels indicate the seasonal changes in Chla, BOD, and $C O D$ in the study sites, respectively. Correlation's of Chla with $\operatorname{BOD}(O)$ and $\operatorname{COD}(+)$ were shown in the right panels and their correlation curves were illustrated in light (-) and broken (--) lines, respectively. Correlation coefficients were also indicated in the graphs, respectively.
Fig. 3 Seasonal changes and correlation between Chl.a with IC and $\mathrm{pH}$ in the North Port sea-based dredged soil disposal site south station. Heavy (-), light (-), and broken (-.-) lines in the panels (A) indicate the seasonal changes in Chl.a, $\mathrm{pH}$, and IC in the study sites, respectively. 


\section{2 光合成とpHの関係}

$2 \cdot 3$ 区の余水における高 $\mathrm{pH}$ の支配因子を明らかにす るために, 無機炭素濃度やアルカリ度等の変動から $\mathrm{pH}$ の 変動を計算した。

海水の $\mathrm{pH}$ 支配しているのは炭酸塭濃度であり, 炭酸 の溶解平衡反応は以下の式に現すことが出来る。

$$
\begin{aligned}
& \mathrm{CO}_{2}(\text { gas })+\mathrm{H}_{2} \mathrm{O} \rightleftarrows \mathrm{CO}_{2}(\mathrm{aq})+\mathrm{H}_{2} \mathrm{O} \\
& \mathrm{CO}_{2}(\mathrm{aq})+\mathrm{H}_{2} \mathrm{O} \rightleftarrows \mathrm{H}_{2} \mathrm{CO}_{3}(\mathrm{aq}) \\
& \mathrm{H}_{2} \mathrm{CO}_{3} \rightleftarrows \mathrm{H}^{+}+\mathrm{HCO}_{3}^{-}
\end{aligned}
$$

$$
\mathrm{HCO}_{3}{ }^{-} \rightleftarrows \mathrm{H}^{+}+\mathrm{CO}_{3}{ }^{2-}
$$

式(3)と(4)の解離平衡定数はそれぞれ, 式(5)と(6)で与え られる。

$$
\begin{aligned}
& \mathrm{K}_{1}=10^{-6.35}=\left[\mathrm{H}^{+}\right]\left[\mathrm{HCO}_{3}^{-}\right] /\left[\mathrm{H}_{2} \mathrm{CO}_{3}\right] \\
& \mathrm{K}_{2}=10^{-10.33}=\left[\mathrm{H}^{+}\right]\left[\mathrm{CO}_{3}{ }^{2-}\right] /\left[\mathrm{HCO}_{3}{ }^{-}\right]
\end{aligned}
$$

式(5)と(6)から式(7)が導かれるので, 炭酸濃度と $\mathrm{pH}$ の関 係は(8)で表すことが出来る。

$$
\begin{aligned}
& \mathrm{K}_{1} \mathrm{~K}_{2}=\left[\mathrm{H}^{+}\right]^{2}\left[\mathrm{CO}_{3}{ }^{2+}\right] /\left[\mathrm{H}_{2} \mathrm{CO}_{3}\right] \\
& \mathrm{pH}=\frac{1}{2}\left(\mathrm{pK}_{1}+\mathrm{pK}_{2}\right) \frac{1}{2}+\log \frac{\left[\mathrm{CO}_{3}{ }^{2-}\right]}{\left[\mathrm{H}_{2} \mathrm{CO}_{3}\right]}
\end{aligned}
$$

分析して得られた濃度を用いて計算を行うためには， 活量 $\left(\mathrm{a}_{\mathrm{x}}\right)$ に対して成り立つ上述の解離定数の式(5)(6)を, 分析モル濃度 $\left(m_{x}\right)$ と活量係数 $\left(\gamma_{\mathrm{x}}\right)$ を用いて書き直 す必要がある。

$$
\begin{aligned}
& \mathrm{K}_{1}=\frac{\mathrm{aH}^{+} \cdot \gamma \mathrm{HCO}_{3}^{-} \cdot \mathrm{m}_{\mathrm{HCO}_{3}}^{-}}{\gamma \mathrm{H}_{2} \mathrm{CO}_{3}^{-} \cdot \mathrm{m}_{\mathrm{H}_{2} \mathrm{CO}_{3}}} \\
& \mathrm{~K}_{2}=\frac{\mathrm{a}^{+} \cdot \gamma \mathrm{CO}_{3}{ }^{-} \cdot \mathrm{m}_{\mathrm{CO}_{3}}^{-}}{\gamma \mathrm{HCO}_{3}^{-} \cdot \mathrm{m}_{\mathrm{HCO}_{3}}^{-}} \\
& \mathrm{pK}_{1}=\mathrm{pK}_{1}{ }^{\prime}+\log \frac{\gamma \mathrm{H}_{2} \mathrm{CO}_{3}}{\gamma \mathrm{HCO}_{3}} \\
& \mathrm{pK}_{2}=\mathrm{pK}_{2}{ }^{\prime}+\log \frac{\gamma \mathrm{HCO}_{3}^{-}}{\gamma \mathrm{CO}_{3}{ }^{2-}}
\end{aligned}
$$

ここで,

$$
\mathrm{K}_{1}^{\prime}=\frac{\mathrm{aH}^{+} \cdot \mathrm{m}_{\mathrm{HCO}_{3}}^{-}}{\mathrm{m}_{2} \mathrm{CO}_{3}} \quad \mathrm{~K}_{2}{ }^{\prime}=\frac{\mathrm{aH}^{+} \cdot \mathrm{m}_{\mathrm{CO}_{3}{ }^{2-}}}{\mathrm{mHCO}_{3}{ }^{-}}
$$

上述の反応式は希薄溶液中で成り立つものであるが, 海 水に溶存する炭酸塩類の平衡状態を左右する主な要因は $\mathrm{aH}^{+}(\mathrm{pH}), \mathrm{Ac}, \Sigma \mathrm{CO}_{2}$ などであり，これらを測定するこ とにより推定することが出来る ${ }^{10 !}$ 。

$$
\mathrm{K}_{2}^{\prime}=\mathrm{aH}^{+} \cdot \frac{\mathrm{Ac} \cdot\left(1+\mathrm{aH}^{+} / \mathrm{K}_{1}^{\prime}\right)-\Sigma \mathrm{CO}_{2}}{2 \Sigma \mathrm{CO}_{2}-\mathrm{Ac}}
$$

ここで, $\mathrm{aH}^{+}$は水素イオンの活量であり, $\mathrm{pH}$ メータで 測定される值である。 $\Sigma \mathrm{CO}_{2}$ は全無機炭酸濃度, $\mathrm{Ac}$ は炭 酸に由来するアルカリ度のことで, $\mathrm{Ac}=\mathrm{m}_{\mathrm{HCO}_{3}}{ }^{-}+2$ $\mathrm{mCO}_{3}{ }^{2-}$ で表される。海水の場合，アルカリ度（At）に影 響を及ほすものとしてホウ酸を考慮しなくてはならない。 At とAcの関係は式(14)で与えられる。

$$
\begin{aligned}
& \mathrm{B}(\mathrm{OH})_{3}+\mathrm{H}_{2} \mathrm{O} \rightleftarrows \mathrm{B}(\mathrm{OH})_{4}{ }^{-}+\mathrm{H}^{+} \\
& \mathrm{K}_{\mathrm{B}}{ }^{\prime}=\left(\mathrm{m}_{\mathrm{B}(\mathrm{OH})_{4}}{ }^{-} \cdot \mathrm{aH}^{+}\right) / \mathrm{m}_{\mathrm{B}(\mathrm{OH}) 3} \\
& \mathrm{At}=\mathrm{Ac}+\mathrm{mB}_{(\mathrm{OH}) 4^{-}}=\mathrm{Ac}+\Sigma \mathrm{B} /\left(1+\mathrm{aH}^{+} / \mathrm{KB}^{\prime}\right)
\end{aligned}
$$

$\mathrm{K}_{1}{ }^{\prime}, \mathrm{K}_{2}{ }^{\prime}, \mathrm{K}_{\mathrm{B}}{ }^{\prime}$ の值は, 実験的に次式で与えられている ${ }^{101}$ 。

$$
\begin{aligned}
\mathrm{pK}_{1}{ }^{\prime}= & 3404.71 / \mathrm{T}+0.032786 \cdot \mathrm{T}-14.7122 \\
& -0.19178 \cdot \mathrm{Cl}^{13} \\
\mathrm{pK}_{2}{ }^{\prime}= & 2902.39 / \mathrm{T}+0.02379 \cdot \mathrm{T}-6.4710 \\
& -0.4693 \cdot \mathrm{Cl}^{1{ }^{3}} \\
\mathrm{pK}_{\mathrm{B}}{ }^{\prime}= & 2291.90 / \mathrm{T}+0.01756 \cdot \mathrm{T}-3.3850 \\
& -0.32051 \cdot \mathrm{Cl}^{13}
\end{aligned}
$$

ここで， $\mathrm{T}$ : 絶対温度 $(\mathrm{K}), \mathrm{Cl}$ : 塩素濃度 $(\%)$ 。 全ホウ素濃度 $\Sigma \mathrm{B}$ は塩素濃度に比例する保存量と考え ることが出来るので11，塩分 $35 \%$ の海水中のホウ素濃度 $\left.0.416 \mathrm{~mm}^{11}\right)$ と分析で得られた塩素濃度から求め, 式(13)の $\mathrm{aH}^{+}$は1999年 7 月 7 日の実測值を初期值として与え，以 降は計算で得られた前週の $\mathrm{pH}$ 用い, 分析で得たAtと(17) を代入してAcを求めた。 $\Sigma \mathrm{CO}_{2}$ は全無機炭酸 (IC) を用 いることで，式(11)から $\mathrm{aH}^{+}$を求め，推定 $\mathrm{pH}$ を得た。計算 で得られた $\mathrm{pH}$ は実測 $\mathrm{pH}$ の変動を良く表しており，炭酸 塩の平衡状態が海水の $\mathrm{pH}$ 支配していることが理解で きる(Fig.4)。

Table 1 で得られたChl. $a$ 濃度と pHの間の相関は有為 に高かったが，Chl. $a$ とICの間には1区（P 4 ）を除き 相関関係が認められなかった。そこで，植物プランクト 


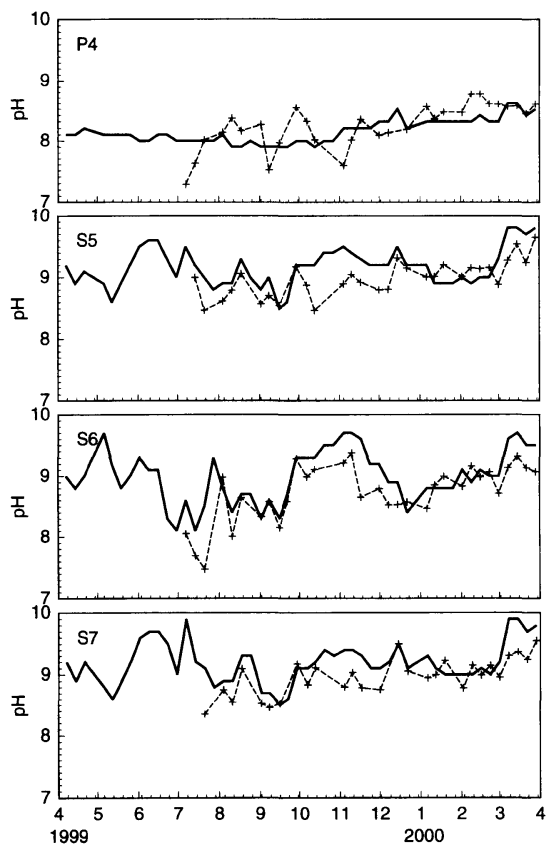

Fig. 4 Seasonal changes in pH in the North Port seabased dredged soil disposal site south station. Values of $\mathrm{pHs}$ calculated from IC were indicated in broken lines (-+-) and compared with the observed values (-).
ンの現存量を別の指標を用いて表す必要があると考え, POCを測定してChl. $a$ およびICとの比較を行った。S7の 例をFig. 5に示す。Chl. $a$ とPOCの間には高い相関 $(\mathrm{r}=$ $0.823 ）$ が得られ, Chl. $a$ と POCの間の変換率は $34 \mathrm{mg} \mathrm{C} /$ mg Chl. $a$ であった（Fig. 5A-right）。これは, 星加らの報 告と良く一致している ${ }^{12 !}$ 。しかしながら，POCとICの間 には明瞭な関係を見いだすことは出来なかった（r= -0.144） (Fig.5B-right)。

IC と $\mathrm{pH}$ の変動は比較的良く対応しているが (Fig. 3), POC とICの間に関連がないので, 植物プランクトンの増 殖以外にも雨水による内水の希釈などIC濃度を支配す る要因があることを伺わせる結果となった。試みに塩素 イオン濃度の変化から希釈による $\mathrm{pH}$ の影響を検討し たが関係は低いと考えられた（Fig. 5C)。

各項目間の関係をより詳細に検討するために, $\mathrm{pH}$ 推 定するのに用いた各項目にChl. a 加えて, S5からS7地 点の92個のデータ対に関して重回帰分析を行った。得ら れた標準偏回帰係数から, pHの変動にはICとアルカリ度 の寄与率が高く, クロロフィル濃度の寄与率は水温より も低いことが判った（Table 2)。また，独立変数にPOC (懸濁態有機炭素) を加え, ICの変動と植物プランクト ンの増殖の間にどの程度関連があるのか重回帰分析を行 った（Table 3 ）。ICはpHやアルカリ度の変動に支配さ れており, 植物プランクトンの変動の指標となる POCや Chl.aの寄与率はきわめて低かった。一方, Chl.aはPOC
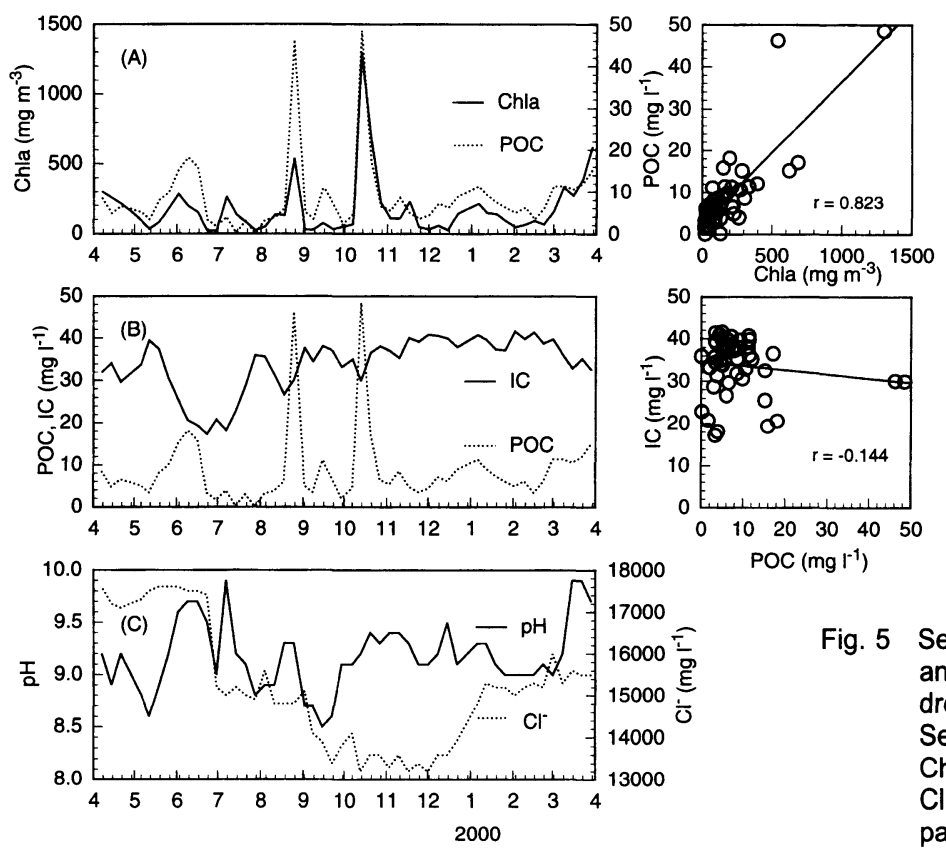

Fig. 5 Seasonal changes in Chl.a, POC, IC, pH, and $\mathrm{Cl}^{-}$in $\mathrm{S} 7$ in the North Port sea-based dredged soil disposal site south station. Seasonal changes in POC (-) and Chl.a (-- ), POC (-) and IC (-- ) , and $\mathrm{Cl}^{-}(-)$and $\mathrm{pH}(--)$ were illustrated in panels $A, B$ and $C$, respectively. 
Table 2 Standardized regression coefficient $(\beta)$ against $\mathrm{pH}$.

\begin{tabular}{lccccc}
\hline & temperature & $\mathrm{Cl}^{-}$ & IC & alkalinity & Chl. a \\
\hline$\beta$ & 0.316 & -0.175 & -0.749 & 0.664 & 0.217 \\
\hline & & & & $\mathrm{n}=95$
\end{tabular}

Table 3 Standardized regression coefficient against IC and POC.

\begin{tabular}{crrrrrr}
\hline & $\mathrm{pH}$ & temperature & IC & POC & alkalinity & Chl. a \\
\hline IC & -0.606 & -0.135 & & 0.026 & 0.751 & -0.009 \\
POC & 0.151 & -0.075 & 0.042 & & -0.177 & 0.624 \\
\hline \multicolumn{1}{r}{} & & & & & & $n=92$
\end{tabular}

の主要な変動因子であった。

一般的に，植物プランクトンが増殖すれば，光合成に 伴う炭酸同化作用により海水中の溶存態 $\mathrm{CO}_{2}$ が減少する ので式(2)（4)は平衡が左にずれ， $\mathrm{pH}$ が高くなると考え られているが, ICの変動は植物プランクトンの増殖に伴 う炭酸の消費を説明できなかった。光合成で同化される 水和炭酸は大気からの溶解や水中微生物の代謝に伴い常 に供給されるので, 消費と供給速度が拮抗するか速やか に回復すればIC や pHの変動は著しくなくても植物プラ ンクトンの増殖に伴う POCが増加するので, POCあるい はChl. $a$ と $\mathrm{pH}$ は単純な比例関係にはならないものと考え られる。

以上の結果から, 水底土砂処分場内水の水質悪化の主 要な要因は植物プランクトンの増殖によるものであり, 水質を良好に保つためには植物プランクトンの増殖を抑 制する対策が必要であることが判った。

\section{4. まとめ}

○処分地余水の高 $\mathrm{pH}$ 垫閴となっているので, $\mathrm{pH}$ の変 動を $\mathrm{IC}$ 等の濃度変化から推定することを試み, $\mathrm{pH}$ ICとアルカリ度の変動から推定することが出来た。

○植物プランクトンが増殖しても IC の変化はPOCの変 化を説明できないことから，消費された炭酸は溶存し ている重炭酸イオンからよりも大気から供給される速 度が速いと考えられる。

$\circ \mathrm{pH}$ と植物プランクトンの現存量の間には高い相関関 係が認められなかったが, $\mathrm{pH}$ の上昇は水和炭酸濃度 の減少によるものであり，植物プランクトンによる光 合成に伴う炭酸同化作用に起因することが明らかにな った。

$\circ$ Chl. $a$ と BOD $\mathrm{COD}$ との相関が高く, 有機物量の増減
は植物プランクトンの増殖に伴う内部生産によるもの であると考えられた。

これらのことより，水質を良好に保つためには植物 プランクトンの増殖を抑制する対策が必要であること がわかった。

\section{5. 謝辞}

本調査を行うに当たり，大阪市環境事業局の関係各位 にお世話になりましたことを深謝します。植物プランク トンの同定には(株モリエコロジーにお世話になりました ことを媣謝します。また，山本攻博士に有益な議論をし ていただいたことを深謝いたします。

\section{参考文献}

1）村上和仁，鷹野洋，吉岡敏行，荻野泰夫：COD およ び栄養塩類からみた児島湖の水質特性の解析：全国 公害研会誌，23，231-239（1998）

2 ) 白谷栄作, 井上久義, 塩福輝雄, 久保田富次郎 : 有 明海沿岸農業地帯の植物プランクトンの増殖と水質 要因との関係：農業土木学会論文集，178，61-69 (1995)

3 ) 森鐘一：高率酸化池と安定化池における浮遊生物の 出現状況, 廃棄物学会誌, 6, 310-321（1995）

4 ) Mori, S., I. Fukunaga, T. Nakamura, Z. Inoue, and K. Takamizawa:Phytoplankton population succession in hyper-eutrophic stabilization ponds located at a sea based dredged sludge disposal site, Jpn. J. Wat. Treat. Biol. 32, 161-171(1996)

5 ) 坪田博行 : 溶液としての海水, 海洋科学基礎講座 10 , 海水の化学, p26-78, 東海大学出版会, 東京 (1970)

6 ) 原島 省, 功刀正行：海の働きと海洋污染, 裳華房, 東京（1997）

7 ）日本規格協会：工場排水試験方法, JIS K0102 (1994)

8 ）日本分析化学会北海道支部編 : 水の分析, 化学同人, 京都 (1981)

9 ) 気象庁編：海洋観測指針（1990）

10）北野康：溶液化学－炭酸物質の挙動を中心として, 大場忠道他著, 海洋学講座6, 海洋無機化学, p7-49, 東京大学出版会, 東京 (1975)

11）金森悟：物質の分布とそれをもたらす要因一非金属, 海洋科学基礎講座10, 海水の化学, p297-330, 東海 大学出版会, 東京 (1970)

12）星加章, 谷本照巳, 三島康史：大阪湾における富栄 養化と内部生産有機物, 水環境学会誌, $21,765-771$ (1998)

13) Horne, A. and C. R. Goldman : 手塚泰彦訳, 陸水学, 京都大学学術出版会, 京都 (1999)

(受付 2000.11.1)

(受理 2001.4.18) 